Hana Komlenac

Zagreb

hanakomlenac@gmail.com
DOI 10.32458/ei.25.11

UDK 069.42(497.521.2):39 005.92:069](497.521.2)

Professional paper

Received: $20^{\text {th }}$ May 2020

Accepted: $18^{\text {th }}$ June 2020

\title{
The Hemerotheque of the Ethnographic Museum in Zagreb
}

The paper provides an overview of the process of systematisation and digitisation of the hemerotheque collection at the Ethnographic Museum, with an emphasis on understanding of the concept of hemerotheque over one hundred years of operations of the Museum. The introductory part provides a presentation of the hemerotheque within the theoretical and legislative framework based on which the work on the paper started in 2019. Furthermore, the text provides insights that preceded the current state of affairs of the hemerotheque, which includes an analysis of the collection and the policy of collection of hemerotheque materials. In addition to the digitisation process implemented thus far and processing of the hemerotheque materials, the paper also addresses contemporary practices.

Key words: Ethnographic Museum (Zagreb)

documentation, hemerotheque, museum history

\section{INTRODUCTION}

Since the start of museum operations, materials were collected within the documentation of the Ethnographic Museum in connection with museum objects, museum activities and the professional work of its employees, as well as the hemerotheque collection. This text presents the structure and development of the hemerotheque over one hundred years of operations of the Ethnographic Museum. Professional literature that was used 
in the research referred to history, organisation and museum activities, the laws and bylaws in force, as well as the references in connection with museum documentation. ${ }^{1}$

The specific objective of the text is to provide a historical overview of the formation of the Hemerotheque collection at the Ethnographic Museum, as well as to present (own) work on the hemerotheque and the plans concerning the future processing of the materials.

The introductory part of the text provides a brief overview of the concept of museum documentation and hemerotheque within the theoretical and legislative framework in order to show that museum documentation was defined by laws relatively late and so was the hemerotheque. A chapter ensues that is intended to present the history of museum documentation and documentation collections of the Ethnographic Museum in Zagreb.

The following chapter presents the current state of affairs of the Hemerotheque collection that preceded materials processing and collection analysis. The final chapter provides an overview of the digitisation process and materials processing to date in the Hemerotheque collection, as well as an analysis of the digitised collection.

\section{THE HEMEROTHEQUE AND MUSEUM DOCUMENTATION THROUGH THEORY AND LEGISLATIVE FRAMEWORK}

The paper presents theoretical hypotheses about methods of museum documentation management based on the scientific work of the art historian and museologist Ivo Maroević in relation to existing laws and practices in everyday situations. According to Ivo Maroević, museum documentation is as follows:

"the process of recording data and information that, during the research, observation or interpretation of a museum object, was transferred to another medium, in order to enable us to use them with a specific knowledge about the issue. It is a specific form of materialising information in order to preserve it and the possibility to transfer it through other media. The purpose of documentation is to provide the most valuable possible idea of the object in question, from all the aspects of human interest." (Maroević 1993: 190)

Over the years, the importance, volume and method of documentation processing changed through laws. The first list $^{2}$ that more closely defined content, forms and methods of museum documentation management was "The Ordinance on the Content and the Method of Management of Museum Documentation of Museum Collections" (OG 108/2002). The latter Ordinance divided the documentation into primary, secondary and tertiary, defining it as

1 The Hemerotheque of the Ethnographic Museum in Zagreb was the topic that I addressed in the written part of my state licence exam for the profession of curator in 2020.

2 Guidelines on documenting of museum and gallery objects were provided in 1987 in the journal "Muzeologija" No. 25. 
"systematically prepared, collected, organised and stored data sets, resulting from the course of the process of professional processing, protection and presentation of museum collections. It is based on agreed upon and determined number and quality of data about an object, a group of objects or an entire pool. Museum documentation is created during the process of keeping a collection inventory, cataloguing and indexing, all of which are a continuous process of upgrade and processing of data." (OG 108/2002, Article 2)

"The purpose of managing museum documentation is to provide accurate information about museum collections, their condition, exhibitions, other events and museum activities, as well as about the history of the museum both from the professional and scientific aspect through clear and systematically processed holdings." (OG 108/2002, Article 3)

Hemerotheque (Greek. ỳ $\mu \varepsilon ́ p \alpha$ : day + -theque: receptacle, chest) is, according to the Croatian Encyclopedia

"a collection of newspapers or magazines; a collection of clippings from actual newspapers, magazines or any other printed materials about specific, previously established topics or objects, normally arranged in accordance with the alphabetical or chronological order of hints. It is used in libraries or other information institutions as a fast source of information, as well as for additional information, primarily about actual topics and events." ${ }^{3}$

Maroević divided documentation according to content and function and identified three groups: primary, secondary and tertiary documentation. Primary documentation results from direct contact with objects and the data about them is collected through "research, preservation and communication of heritage objects, it includes the knowledge of them and all the types of events in them and around them or the events of which the object in question is the subject or the object." (Maroevic 1993: 191-192) According to the same author, primary documentation also includes document collection items, such as hemerotheque or newspaper archives. ${ }^{4}$

Prior to the passing of the "The Ordinance on the Content and the Method of Management of Museum Documentation of Museum Collections" in 2002, hemerotheque was a broader term ${ }^{5}$ for museum professionals. The Ethnographic Museum in Zagreb is an example of the latter and hence the hemerotheque also included a poster collection that was preserved in the library. According to The Ordinance hemerotheque includes newspaper and magazine content about museum collections, exhibitions and other programme activities, the history of the institution and its professional staff (OG $108 / 2002$, Article 27). It is included in secondary documentation and processing of these collections is a legal obligation.

3 https://www.enciklopedija.hr/Natuknica.aspx?ID = 24926 (visited on the $14^{\text {th }}$ February 2020).

4 Secondary documentation includes the transfer of primary documentation into other media (microfilm, magnetic tapes, floppy disks). Tertiary documentation comprises of "revisions, card catalogues, catalogues, indexes, lists and all the other forms of revision of documentation" (Maroević 1993: 192-193).

5 The latter has been confirmed by the example of the Museum of Slavonia whose hemerotheque collections include "newspapers, clippings, posters and screen prints that used to be brought to the museum in huge quantities and were arranged in other departments." (Vinaj 1998: 62). 
Against the backdrop of technological development and the appearance of new media, the latest ordinance about documentation in preparation in accordance with the Museums Act from 2018 is supposed to broaden the definition and understanding of hemerotheque collections. Hence, the term hemerotheque would not include only printed press, but also all the media releases (television, radio, Internet portals).

\section{HISTORY OF MUSEUM DOCUMENTATION AND DOCUMENTATION COLLECTIONS OF THE ETHNOGRAPHIC MUSEUM}

"1919 saw the foundation of the Ethnographic Museum in Zagreb. Prior to the previously mentioned year, the ethnographic materials were collected at the National Museum that was founded in Zagreb in 1846. Upon the initiative of the Department of Religion and Education, 1919 saw the merger of the existing ethnographic collections with a large textile collection of Salamon Berger into an independent Ethnographic Department of the Croatian National Museum - the existing Ethnographic Museum in Zagreb." ${ }^{\prime 6}$

Since the inception of the museum, museum documentation has been managed in connection with museum objects (inventory control registers, museum object accession and museum object deaccessioning records). Some documentation collections were introduced immediately upon the foundation, such as film negative inventory registers, photo archives, slide archives, as a result of intensive field research. "Among more important research, it is important to highlight Pokuplje Ethnographic Expedition from 1923. The materials were collected for the purpose of studying, recognising the field and research of ethnographic topics using photography, film and phonograph records." (Vlatković 2019: 66) It is primarily due to the latter that Vladimir Tkalčić, the first curator of the Ethnographic Museum, was aware of the importance of documentation collection and he stated as follows:

"Out of auxiliary museum institutions, without which a modern museum cannot even be imagined, the museum archives have been well arranged. It includes different original ethnographic materials in the form of manuscripts, photographs, drawings, as well as film negative archives and a special non-European archives; reference library, which had to be established again from scratch and it now includes around 1500 issues; drawing and painting ateliers, ateliers for taking photography using several cameras and all the other necessary equipment and devices; technical workshops for various carpentry, ironmongery and similar works, as well as for museum object conservation." (Tkalčić 1930: 143)

Since the start of museum operations, the documentation of the Ethnographic Museum has been collected concerning museum objects, museum activity, professional work

6 http://www.emz.hr/O\%20muzeju/Povijest\%20muzeja (visited on the $14^{\text {th }}$ February 2020). 
and papers of the museum staff, as well as different correspondence, reports, logs, normative acts and other similar material. Most materials were collected and stored in Documentation, yet without detailed lists, records or inventory control registers. The exception to the latter were audivisual materials concerning which inventory control registers were kept (film negative inventory registers, slide archives, photo archives). These were introduced immediately upon the foundation of the Museum thanks to Vladimir Tkalčić.

It needs to be pointed out that, in addition to inventory control registers of museum and documentation collections, map library was managed with catalogue cards in accordance with the inventory number and the type of object and locality (Vlatković 2019: 65-70). The Documentation of the Ethnographic Museum in Zagreb is currently managed in accordance with the laws currently in force, primarily with the Museums Act (OG 61/2018) and "The Ordinance on the Content and the Method of Management of Museum Documentation of Museum Collections" (OG 108/2002). ${ }^{7}$

\section{THE HEMEROTHEQUE OF THE ETHNOGRAPHIC MUSEUM}

The hemerotheque was mentioned in the "Rules of the Ethnographic Museum" from 1961, the first known museum act that passed regulations on internal organisation. The latter, as well as the "Bylaws of the Ethnographic Museum" from 1966, stated that the Documentation Department records both accessioning and deaccessioning of museum objects, manages the archives and the hemerotheque, photo archives, slide and film archives, as well as audio collection.

The Bylaws of the Ethnographic Museum in Zagreb were passed in 1970 and in 1971 and they did not mention hemerotheque management. The hemerotheque was yet again mentioned in the "Ordinance on Systematisation of Workplaces in the Ethnographic Museum in Zagreb" from 1977, according to which it was managed at the museum library (Gjetvaj 1989: 56). ${ }^{8}$ In 2005 the "Bylaws of the Ethnographic Museum" were passed, according to which the hemerothque was managed in the Museum Documentation (within the Department for Collections and Documentation), in accordance with the existing "Ordinance on the Content and the Method of Management of Museum Documentation of Museum Collections" (OG 108/2002) and in the same year the hemerotheque was excluded from the library.

7 Primary documentation of the Ethnographic Museum is managed using the software for the processing of museum collections $\mathrm{M}++$. Secondary documentation is managed in the relational database $\mathrm{S}++$. The existing system of museum collection and documentation processing manages tertiary documentation through a control of terms, which is achieved through the use of controlled dictionaries and thesauruses, in an effort to improve both the accessibility and the quality of the search (Vlatković 2019: 70-71).

8 In accordance with the "Ordinance on Systematisation of Workplaces in the Ethnographic Museum" from 1980 and 2002 and the "Bylaws of the Ethnographic Museum" from 2000, the hemerotheque is also managed at the museum library. A reference library was founded upon the foundation of the museum and in 1920, it was founded as a separate museum department. Museum employees of different professions were in charge of running and managing the museum library until 1995 when Irena Kolbas was employed as the first librarian at the Library of the Ethnographic Museum Zagreb (Kolbas 2019: 75, 82). 
The hemerotheque collections management in the Ethnographic Museum in Zagreb started in 2017 when the texts that reached the museum since January 2017 were processed. 2019 saw the start of processing and digitisation of the materials collected from the foundation of the museum to 2016 and the author of the text was involved in the latter process. ${ }^{9}$

During the assessment of the status of hemerotheque collections by the end of 2018 and in 2019, two files with newspaper clippings (Berger, Franić) were found in the Documentation of the Ethnographic Museum, 32 folders, as well as the newspaper articles accompanying exhibitions that were inserted in the files. ${ }^{10}$ The Berger file includes original newspaper articles from both national and international press in connection with the foundation and the work of the Ethnographic Museum in Zagreb and with the life and work of Salamon Berger, the first director of the Museum (from 1919 to 1930). The Franić file comprises of 29 cardboard files with glued down newspaper clippings that addressed everyday topics with some newspaper text clippings in connection with the work of the Ethnographic Museum published during the period from 1936 to 1939 , when Ivo Franić was the director of the Ethnographic Museum.

The previously mentioned 32 folders contained newspaper clippings published during the period from 1945 to 2016. The newspaper articles were arranged in folders according to years and the text content (musem, various). Older folders included original newspaper articles primarily addressing ethnographic topics and topics linked with exhibitions staged by the Ethnographic Museum. Nevertheless, in the 1990's when co-operation with Presscut ${ }^{11}$ was established, the number of collected newspaper articles increased, as well as the range of topics. Presscut collected newspaper articles that included the following key words: ethnology, ethnography, ethnographic exhibitions, Ethnographic Museum. The latter resulted in hundreds of collected copies of newspaper articles at the monthly level, primarily in connection with the operations of ethnographic institutions that were not directly connected with the Ethnographic Museum in Zagreb. In addition to the copies of newspaper articles received through Presscut, the folders included also preserved printed copies that were primarily (but not exclusively) linked with the operations of the Ethnographic Museum. Starting from 2006, the newspaper articles were saved on CDs, yet the number of received newspaper articles did not decrease until the end of 2010 since when only newspaper articles in connection with the Ethnographic Museum in Zagreb and ethnographic institutions were collected. Starting from 2016, the hemerotheque is no longer saved on CDs, as Presscut has been sending newspaper articles in PDF via e-mail, which are saved in the database for computer processing $\mathrm{S}++$.

9 At the end of 2018, I started my professional development training at the Ethnographic Museum in Zagreb. The first part of the professional training was in connection with primary documentation management with the mentor Aleksandra Vlatković, while during the second part the author of the text started the processing and digitisation of hemerotheque materials that had been collected since the foundation of the Museum.

10 Newspaper clippings found during the revision of exhibitions and the accompanying publishing activities, released during the period from 1919 to 1995.

11 A media monitoring company. 


\section{ARRANGEMENT AND DIGITISATION OF HEMEROTHEQUE COLLECTIONS}

Like most documentation materials, hemerotheque materials have been collected since the foundation of the Museum. Nevertheless, they were not processed and there were no records. Processing and management started in 2017 and digitisation in 2019.

During the preparation for digitisation of hemerotheque materials, all the collected texs were read and selected. In case of newspaper articles published before 2002, no significant selection was made and newspaper articles were integrated irrespective of the topic and arranged in chronological order. The newspaper articles that were published after 2002 were selected in accordance with the criteria stated in the Ordinance from 2002, as agreed with the collection manager and newspaper articles dealing with the issue of museum activity were processed.

The newpaper articles published from the foundation of the museum to the 1990's are linked with ethnographic topics and topics in connection with the museum activity. ${ }^{12}$ Starting from 1999, the number of newspaper articles increased and the topics were more varied. Newspaper articles addressing the issue of museum activity were selected and prepared for digitisation, while the others were stored in two archival boxes. ${ }^{13}$

The materials that were prepared for entry was processed in the database for computer management of documentation collections $S++$ through hemerotheque collection. The following categories were filled upon entry in the database: inventory tag, year, subcollection, text title, text type, author, publication, ISBN/ISSN, publisher, date of issue, information on illustration and language and concise summary (entered under note). When possible, a connection was identified in the database with other documentation collections such as exhibitions. Records were added digital copies. ${ }^{14}$ Newspaper articles were scanned using MICROTEK MRS-3200A3 scanner in TIFF format and processed using Vuescan software in increments of $400 \mathrm{dpi} .{ }^{15}$ The scanned newspaper articles, as well as those delivered in PDF (through e-mail or CD) were saved on an external CD drive and on the server. Digital copies were allocated their corresponding inventory tag.

During the revision of the collections of the Exhibitions in 2019, newspaper articles were found linked with the exhibitions and they were included into hemerotheque collections. The titles of newspaper articles were searched in the database and if it had been concluded that the searched newspaper article was a duplicate, it was allocated a previously existing inventory tag and the latter newspaper article was stored with

12 A part of newspaper clippings included in Franić file are not in connection with ethnology and museum operations and they are not included in inventorying, as stated in a note on the file.

13 The inscription on archival boxes reads "Not on the records $1971-2002$ " and "Not on the records 2003 - 2016 ".

14 For the purpose of inclusion of photography in the database, the size of the digital copies was minimised and converted to JPG format, while those in PDF remained identical to original and there are plans to convert them to JPG.

15 The newspaper articles that were too large to be scanned were marked and prepared for being photographed. The taken photographs will be added to the database entry. 
the article that had previously been inventoried. ${ }^{16}$ Newspaper articles that were not duplicates were inventoried, entered in the database and scanned, as well as saved in the same way as the previous newspaper articles.

As previously stated, several identical copies of newspaper articles have been found. The originals were allocated an identical inventory tag and have been preserved together in the documentation. In cases in which there is both the original and a copy of a newspaper article, the copies were eliminated. In cases in which there is the original newspaper article and a PDF version received on a CD or through e-mail, the original was preserved in the documentation, while the newspaper article in PDF was saved in an external CD drive and on the server and added to the corresponding inventory $\log$ in the database. The copies were also eliminated. After inventorying and material processing, newspaper articles were preventively conserved to safeguard them and stacked neatly in chronological order with the location tag in museum documentation. ${ }^{17}$

The previously mentioned hemerotheque material digitisation process saw 3529 entries in the database $\mathrm{S}++$ and 2892 digital copies. The workplan in the Documentation Department includes content processing of all the newspaper articles in order to make them searchable and accessible to the users.

\section{ANALYSIS OF DIGITISED HEMEROTHEQUE MATERIALS}

At the very start of operations of the Ethnographic Museum in Zagreb, newspaper articles were collected in close connection with the museum foundation and activities, as well as life and work of Salamon Berger. In addition, several newspaper articles were preserved in connection with the handicraft industry exhibition staged by Berger prior to the foundation of the Museum.

The 1930's saw an increase in the collected newspaper articles. Out of 509 digitised newspaper articles, 395 were the newspaper articles from Franić file. They addressed the issue of everyday life, while the remaining 114 newspaper articles were linked with the communication between Ivo Franić and Milovan Gavazzi, different ethnographic topics and the funeral of S. Berger. During the latter period, newspaper articles in connection with the exhibitions staged by the Ethnographic Museum were not collected. ${ }^{18}$

From 1940 to the end of 1969, the collected newspaper articles were primarily in connection with the exhibitions staged by the Ethnographic Museum.

The 1970's yet again saw a rise in the collected newspaper articles. They comprised of newspaper articles in connection with exhibitions and the opening of the renovated museum and a new permanent exhibition. Moreover, the collected newspaper articles addressed a wide range of ethnographic topics. In the 1980's there was a continuation

16 In case of existence of several copies of the same newspaper article, I stated it under the category Note.

17 The materials have been cleaned and preserved in acid-free file folders.

18 During the revision of the collections of Exhibitions, it was concluded that screen prints and posters in connection with exhibitions held in the 1930's were not collected. 
Graph 1. The inventoried newspaper articles whose date was not determined, were not included in the statistics.

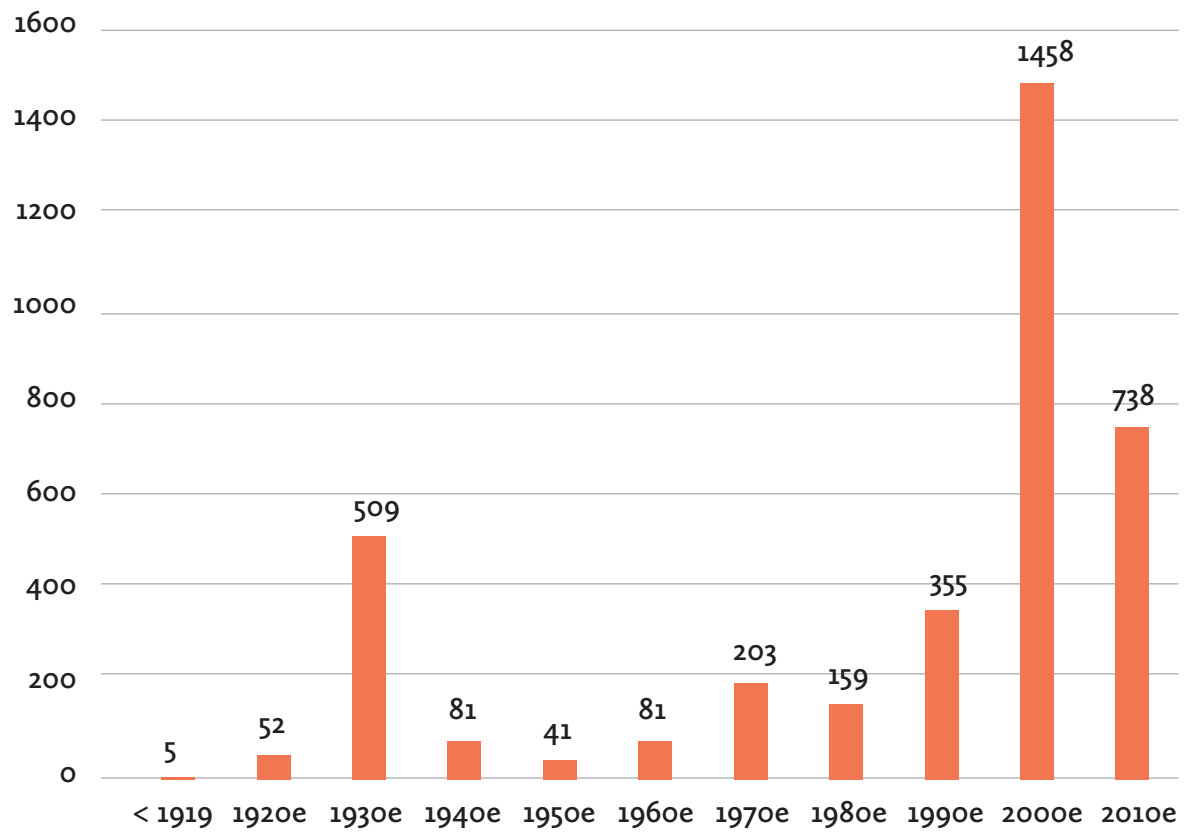

of the practice of newspaper article collection that primarily concerned the museum operations. From 1990's onwards, there was a previously mentioned increase in the newspaper articles collected through Presscut. Irrespective of the fact that the collected newspaper articles covered a wide range of topics, only newspaper articles in connection with museum operations and its employees were digitised.

Throughout the collection of the hemerotheque materials during the period from 1919 to 2016, newspaper articles from both national and international press were collected, while those from international press were primarily original newspaper articles in connection with exhibitions staged by the Ethnographic Museum (touring exhibitions).

A conclusion can be reached from the analysis that there was a practice of collecting hemerotheque materials addressing different ethnographic topics. Nevertheless, a continuity in collecting is noticeable and so is the awareness of the importance of documenting museum activity since the foundation of the Museum. The newspaper articles that were digitised were primarily reviews (1217) and Ethnographic Museum exhibition announcements (669). The digitised newspaper articles were primarily published in the newspapers Večernji list (560) and Vjesnik (431). 


\section{CONCLUSION}

The importance, the volume and the position of documentation has changed through a century of operations of the Ethnographic Museum in Zagreb. Documentation about museum and documentation (audiovisual materials) materials have been managed since the very start of museum operations. ${ }^{19}$ Since prior to the passing of the "Ordinance on the Content and the Method of Management of Museum Documentation of Museum Collections" in 2002 there were no rules on how to access the hemerotheque and in what way to collect such materials, museums had the freedom to decide on the formation of their own hemerotheque collections. Hence, also the Ethnographic Museum in Zagreb, which has been collecting hemerotheque materials since its foundation, over the years saw a changing awareness about what and how to collect. Consequently, newspaper articles addressing different topics (ethnographic, museum science, as well as many others) were collected, while the materials were moved back and forth from documentation to the library and vice versa.

Following an analysis of the hemerotheque materials collection policy since the foundation of the museum, a conclusion can be reached that attention has been continuously paid to collecting newspaper articles about museum operations and its employees since the very start. Notwithstanding the fact that the collected hemerotheque materials were initially not selected and processed, it is evident that there has been an awareness about the importance of recording information about museum operations since the very foundation and the focus has primarily been on newspaper articles in connection with the exhibitions staged by the Ethnographic Museum.

Through digitisation, continuation with collecting hemerotheque materials and further plans of content processing of all the newspaper articles (topics, persons, geographic and temporal determinants) will enable the searchability and accessibility of information about museum operations for the users.

Hemerotheque collections include important documentation materials that provide a wide range of information about museum activities and its employees and it can be used for the purpose of research, exhibitions and revision of other museum collections.

\section{REFERENCES AND SOURCES:}

GJETVAJ, Nada. 1989. "Etnografski muzej u Zagrebu - u povodu 70. obljetnice”. Etnološka istraživanja 5: 1-144.

KOLBAS, Irena. 2019. "Knjižnica Etnografskoga muzeja u Zagrebu” Etnološka istraživanja 24: $75-84$.

MAROEVIĆ, Ivo. 1993. Uvod u muzeologiju. Zagreb: Zavod za informacijske studije Odsjeka za informacijske znanosti, Filozofski fakultet Sveučilišta u Zagrebu.

Inventory books, records, catalogues. 
MAROEVIĆ, Ivo. 2000. "Informacije i dokumentacija u muzejima”. Informatica museologica 31/1-2: 13-15.

Pravila Etnografskog muzeja, 1961., Dokumentacija EMZ.

Pravilnik o sadržaju i načinu vođenja muzejske dokumentacije o muzejskoj građi (NN 108/2002)

Pravilnik o sistematizaciji radnih mjesta Etnografskog muzeja u Zagrebu, 1977., Dokumentacija EMZ.

Pravilnik o sistematizaciji radnih mjesta Etnografskog muzeja u Zagrebu, 1980., Dokumentacija EMZ.

Pravilnik o sistematizaciji radnih mjesta Etnografskog muzeja u Zagrebu, 2002., Dokumentacija EMZ.

Statut Etnografskog muzeja u Zagrebu, 1966., Dokumentacija EMZ.

Statut Etnografskog muzeja u Zagrebu, 1970., Dokumentacija EMZ.

Statut Etnografskog muzeja u Zagrebu, 1971., Dokumentacija EMZ.

Statut Etnografskog muzeja u Zagrebu, 2000., Dokumentacija EMZ.

Statut Etnografskog muzeja u Zagrebu, 2005., Dokumentacija EMZ.

TKALČIĆ, Vladimir. 1930. “Etnografski muzej u Zagrebu 1919 - 1929”. Narodna starina 9: 132-148.

VINAJ, Marina. 1998. “Hemeroteka Muzeja Slavonije”. Informatica museologica 29/1-2: 62-68.

VLATKOVIĆ, Aleksandra. 2019. "Dokumentacija Etnografskog muzeja u Zagrebu”. Etnološka istraživanja 24: 61-74.

Zakon o muzejima (NN 61/2018).

http://www.emz.hr/O\%20muzeju/Povijest\%20muzeja (visited on $14^{\text {th }}$ February 2020).

https://www.enciklopedija.hr/Natuknica.aspx?ID =24926 (visited on $14^{\text {th }}$ February 2020). 